\title{
BRAZILIAN EFL LEARNERS' AWARENESS ABOUT L2 PHONES: IS MALL PRONOUNCED AS 'MAL'?
}

\section{CONSCIÊNCIA DOS APRENDIZES BRASILEIROS DE INGLÊS SOBRE OS FONES DE L2: MALL SE PRONUNCIA COMO 'MAL'?}

\author{
Hanna Kivistö-de Souza*
}

\begin{abstract}
The aim of this paper was to examine the extent of non-verbalizable knowledge L1 Brazilian Portuguese (BP) learners of English possess about the segmental inventory of the L2. The study had two aims: i) to determine to what extent L1 BP EFL learners are aware of contrastive and non-contrastive L2 segments, ii) to determine which type of segments present the lowest level of awareness. To the date, little research has been carried out about the non-verbalizable aspect of L2 phonological awareness, most studies having relied on participants' verbalization of the acquired knowledge (e.g., KENNEDY \& TROFIMOVICH, 2010; WREMBEL, 2011). Whereas language learners are frequently taught grammar explicitly, pronunciation of the L2 is rarely addressed in the foreign language classroom. Moreover, phonology is in nature less susceptible to conscious processing than other aspects of L2 learning, making the noticing, and especially the explicit explanation, of phonological aspects difficult. Nevertheless, high L2 phonological awareness is beneficial for L2 pronunciation (KIVISTÖ-DE SOUZA, 2015), making its examination a priority in the foreign language classroom context. The participants of the study were 71 advanced EFL learners and 18 native speakers of American English. Participants performed a perception test which presented English segments spoken by native and non-native speakers. The ability to identify pronunciation deviations in the non-native speaker trials was taken as a measure for phonological awareness. The results showed that the L1 BP participants manifested a significantly lower sensitivity to English segmental phonology than the native English speakers $\left(F[1,87]=40.56, p<.001, \eta^{2}=.31\right)$. Pronunciation deviations involving consonants were identified to the greatest extent (52\%), whereas the trials involving short-lag VOTs were identified the poorest (33\%). The results reveal a need for explicit pronunciation instruction and the employment of consciousnessraising activities in the Brazilian EFL classroom.
\end{abstract}

Keywords: Phonological awareness; L2 speech learning; Pronunciation instruction.

\section{RESUMO}

Este trabalho investiga a consciência fonológica em LE de aprendizes brasileiros de inglês. O estudo teve dois objetivos: i) determinar o grau de consciência de aprendizes brasileiros de inglês sobre os segmentos contrastivos e não contrastivos de LE, ii) determinar que tipos de segmentos apresentam o nível mais baixo de consciência. Pouca pesquisa tem sido

\footnotetext{
* Universitat de Barcelona, Barcelona. Espanha. hanna.kivistodesouza@gmail.com http://dx.doi.org/10.1590/010318135071200021
} 
conduzida sobre o tipo de consciência fonológica em LE que não está acessível para reflexão consciente. Na maioria dos estudos tem sido solicitado dos participantes a verbalização do conhecimento adquirido (e.g., KENNEDY \& TROFIMOVICH, 2010; WREMBEL, 2011). Enquanto o ensino da gramática é frequentemente explícito, a pronúncia de LE é raramente ensinada na sala de aula. Além do mais, a fonologia é menos susceptível ao processamento consciente do que outros aspetos da LE, fazendo que o noticing, e especialmente a elaboração explícita, de aspectos fonológicos seja difícil. No entanto, um alto nível de consciência fonológica é benéfico para a pronúncia de LE (KIVISTÖ-DE SOUZA, 2015), fazendo o seu estudo uma prioridade na sala de aula delíngua estrangeira. Os participantes foram 71 alunos de nível avançado em inglês e 18 falantes nativos de inglês americano. Os participantes completaram um teste de percepção que apresentou segmentos de inglês produzidos por falantes nativos e não nativos. A capacidade de identificar pronúncias inadequadas nos estímulos não nativos foi usada como a medida de consciência fonológica. Os resultados mostraram que os participantes brasileiros manifestaram uma sensibilidade significativamente mais baixa à fonologia segmental do inglês que os falantes nativos de inglês $\left(F[1,87]=40.56, p<.001, \eta^{2}=.31\right)$. Erros de pronúncia envolvendo consoantes foram identificados com a precisão mais alta $(52 \%)$, enquanto os estímulos com VOT zero foram identificados com mais dificuldade (33\%). Os resultados revelam necessidade de instrução explícita de pronúncia na sala de aula de inglês para brasileiros.

Palavras-chave: Consciência fonológica; Aquisição fonológica de LE ${ }_{i}$ Ensino de pronúncia

\section{INTRODUCTION}

Acquiring accurate pronunciation of a second language (L2) is a challenging task for adult language learners. Whereas first language (L1) phonology is acquired effortlessly and implicitly, the acquisition of L2 phonology calls for a considerable effort from the part of the learner. On the one hand, accurate perception of L2 phonology requires that the pre-existing L1 neural connections are overridden (ELLIS, 2002). On the other hand, to produce L2 speech accurately, the learners need to reconfigure their articulatory movements, which since early infancy have been wired for the pronunciation of the L1. Finally, a considerable amount of practice is required in order for the L2 speech to be delivered fluently, without hesitations and pauses that may interfere in the communication.

One of the factors which has been shown to aid the development of accurate L2 pronunciation is awareness about the L2 phonology (KIVISTÖ-DE SOUZA, 2015). The role of L2 phonological awareness is especially important for language learners and teachers within the formal classroom setting. This is because determining what aspects of the L2 phonology language learners are aware of and especially, what aspects they are not aware of is crucial for the improvement of learners' pronunciation. Moreover, examination of language learners' L2 phonological awareness is an important step in designing more effective pronunciation teaching 
curriculums, as noted by Alves (2009), who denoted the need of L2 phonological awareness research in the Brazilian EFL context.

The present study was designed to increase the understanding about the under-researched area of non-verbalizable L2 phonological awareness ${ }^{1}$. It further sought to expand the language combinations researched in the field of L2 phonological awareness by testing L1 Brazilian Portuguese learners of English. Whereas few studies have focused on raising L1 Brazilian Portuguese speakers' awareness about English pronunciation (ALVES \& MAGRO, 2011; SILVEIRA, 2002; SILVEIRA \& ALVES, 2009), previous studies have not tested Brazilian Portuguese EFL learners' awareness about English phones in the absence of a specifically designed instructional period.

\section{REVIEW OF LITERATURE}

\subsection{Phonological awareness in the first language}

Phonological awareness as a subfield of language awareness has been extensively studied in relation to L1 literacy acquisition. In this context, phonological awareness has been defined as the ability to detect, segment, manipulate and distinguish between the constituent sounds of words (OAKHILL \& KYLE, 2000). Whereas rime-onset awareness and syllable awareness develop spontaneously through language contact (FOY \& MANN, 2001), awareness about phonemes can only develop through literacy instruction (TARONE \& BIGELOW, 2005). A large number of instruments have been employed to examine the various skills making up L1 phonological awareness. Despite the wide array of instruments, L1 phonological awareness tasks frequently share three characteristics as noted by McBride-Chang (1995). First, the participant listens to one or more aurally presented words or nonwords. Second, the participant is asked to perform some sort of operation (e.g., segment, blend, count, discriminate, detect) on the stimuli. Third, a usually verbal, response is given, although sometimes pointing the correct answer can be adopted in studies with very young children.

L1 phonological awareness research has gained large popularity mainly due to its well-established relation to L1 literacy acquisition: phonological awareness is a

1 The research reported in this manuscript forms part of a doctoral research project in which L2 phonological awareness of Brazilian Portuguese EFL learners at the segmental, phonotactic and suprasegmental domains was examined (KIVISTÖ-DE SOUZA, 2015). Only the results of the segmental domain, whose data were re-analyzed for the purposes of this paper, are reported. 
positive correlate and a strong predictor of reading achievement (e.g., BRADLEY \& BRYANT, 1983; GOSWAMI \& BRYANT, 1990; STANOVICH, 1992; YOPP, 1988). Once L1 literacy is achieved, L1 phonological awareness skills become obsolete as orthographic representations and phonological factors, such as sonority, gain more ground and become more useful when thinking about language (DEFIOR, GUTIÉRREZ-PALMA, \& CANO-MARÍN, 2012; LEHTONEN \& TREIMAN, 2007; SCARBOROUGH, EHRI, OLSON, \& FOWLER, 1998). Consequently, L1 phonological awareness is rarely examined in literate adults.

\subsection{Phonological awareness in the second language}

Contrary to L1 phonological awareness, research on this topic in the L2 has been scarce. Whereas the focus in L1 phonological awareness research is on children, L2 research focuses on adult language learners. Within this framework, L2 phonological awareness is usually understood as explicit, verbalizable knowledge about the L2 phonology (KENNEDY \& TROFIMOVICH, 2010; WREMBEL, 2011, 2013). Participants are frequently asked to verbalize the extent of their knowledge either orally (WREMBEL 2011, 2013, 2015) or in writing (KENNEDY, 2012; KENNEDY, BLANCHET, \& TROFIMOVICH, 2014; KENNEDY \& TROFIMOVICH, 2010). This reporting method has been adopted from language awareness research in which verbal recalls and journal entries have been extensively employed (e.g., ALANEN, 1995; LEOW, 1997; ROSA \& O’NEIL, 1999).

However, several researchers have recognized that awareness about L2 phonology also entails intuitive knowledge which cannot be verbalized (ALVES, 2009; MORA; ROCHDI \& KIVISTÖ-DE SOUZA, 2014, 2015; PISKE, 2008). As such, research on the matter in the L2 must also employ implicit testing methods based on participant's L2 speech performance (perception and production) and sensitivity to acceptable and inacceptable L2 speech patterns. This is especially relevant if we take into account that the vast majority of language learners have not been taught L1 or L2 phonetics and phonology explicitly. Thus, language users are rarely able to verbalize pronunciation rules or think about phonology in analytical terms. Nevertheless, they are able to perceive and produce speech accurately, to detect a regional or a foreign accent, and to identify pronunciation errors and incorrect intonation patterns, to varying extents of accuracy. In other words, adult language users possess large amounts of non-verbalizable knowledge about the phonology of their L1 and L2. 
Phonological awareness based on non-verbalizable knowledge has been examined in only a handful of studies (MORA; ROCHDI \& KIVISTÖ-DE SOUZA, 2014, KIVISTÖ-DE SOUZA, 2015; BAKER \& TROFIMOVICH, 2006; FLEGE \& HAMMOND, 1982; SHOEMAKER, 2014). Both, production and perception tasks have been employed to tap into learners' awareness about specific and generic aspects of the L2 phonology. These studies show that language learners possess some non-verbalizable awareness about subphonemic L2 features such as Voice Onset Time (VOT) and glottal stops (MORA; ROCHDI \& KIVISTÖ-DE SOUZA, 2014, KIVISTÖ-DE SOUZA, 2014; FLEGE \& HAMMOND, 1982; SHOEMAKER, 2014). Research also indicates that language learners who are more aware of their own L2 productions (BAKER \& TROFIMOVICH, 2006) and possess higher awareness about the L2 phonology as a whole (KIVISTÖ-DE SOUZA, 2015) perceive and produce the L2 more accurately.

Due to the small number of studies, we still know little about the development of L2 phonological awareness and its relation to contextual and learner factors. Awareness about the L2 phonology is expected to develop through L2 experience and use (PISKE, 2008), so that advanced language learners should manifest higher levels of awareness than elementary level language learners. This matter is further supported by VanPatten's (1996) postulation about the primacy of the meaning over form: language learners attend to meaning over form and to form only when enough attentional resources are available. Applied to L2 phonology, this translates into that only proficient language learners, whose attentional resources are not needed anymore on deciphering meaning, are able to focus on the form of L2 speech. Moreover, this view suggests that once attention is freed for attending to pronunciation, being comprehensible is preferred over being accurate, and attention is given first to meaning-bearing units (phonemes) and only then to noncontrastive units (allophones).

However, studies addressing the issue have provided inconclusive results. Shoemaker (2014) found a relation between L1 French English majors' awareness about the segmental phonology of the L2 and the amount of language exposure, so that $3^{\text {rd }}$ year students performed better than $1^{\text {st }}$ year students. Nevertheless, other studies have failed to find a relation between language experience and use and awareness about L2 phonology (KIVISTÖ-DE SOUZA, 2015; KENNEDY, 2012; VENKATAGIRI \& LEVIS, 2007). Therefore, the developmental paths, the order and the speed of acquisition of L2 phonological awareness require further research. 


\subsection{Acquisition of English segments by Brazilian Portuguese speakers}

The acquisition of English vowels and consonants by Brazilian Portuguese speakers has been extensively studied through perception and production experiments. This section will review the most common problem areas Brazilian Portuguese EFL learners manifest in the acquisition of English segments.

The vowel inventories of Brazilian Portuguese and English differ in terms of both quality and quantity. The English high front and back vowels, /i-I/ and /u- $/$ /, are frequently assimilated into a single Brazilian Portuguese vowel category, /i/ and /u/, respectively (BAPTISTA, 2006; GONÇALVES, 2014; RAUBER, 2006). Thus distinguishing pairs such as feet-fit or pool-pull is challenging for Brazilian Portuguese learners of English.

The acquisition of two of the English low vowels, /æ/ and $/ \Lambda /$ has also been identified as difficult for Brazilian Portuguese EFL learners due to their nonoccurrence in the L1 vowel inventory. Contrary to the before-mentioned high vowels, the acquisition of $/ æ /$ and $/ \Lambda /$ should be easier, as they would be perceived as new vowels, instead of being assimilated to existing L1 vowels (FLEGE, 1995). However, empirical research indicates that until these new vowels are acquired, they are produced with a quality close to the Brazilian Portuguese $/ \varepsilon /$, converting sad and said into homophones (BAPTISTA, 2006; RAUBER, 2006).

In terms of consonants, the accurate perception and production of the two English interdental fricatives $/ \theta, \mathrm{\partial} /$ poses problems for Brazilian Portuguese EFL learners as these sounds are absent from the L1. Whereas $/ \theta /$ is frequently realized as $[\mathrm{t}],[\mathrm{f}]$ or $[\mathrm{s}], / \mathrm{d} /$ is primarily produced as [d] (REIS, 2006). Another problematic consonant is the velar nasal $/ \mathrm{y} /$ whose inaccurate pronunciation persists even at advanced proficiency levels (ZIMMER, 2004). The velar nasal is frequently substituted by the biphones [nk] or [ng], but may also be fronted and realized as the alveolar [n] (CABAÑERO \& ALVES, 2008). Additionally, some speakers insert an epenthetic vowel after the $/ \mathrm{y} /$ in order to accommodate the L2 syllable structure into Brazilian Portuguese (BAPTISTA \& SILVA FILHO, 2006; CARDOSO, 2005).

The syllable-final position has been identified to be especially troublesome for Brazilian Portuguese speakers as Brazilian Portuguese is very restrictive with consonants appearing in this position. As the lateral /1/ does not occur syllable finally in Brazilian Portuguese, the accurate pronunciation of English syllable-final lateral liquids has been shown to be challenging for Brazilian Portuguese speakers. The vocoid realization of the L1 is frequently transferred into the L2 even at advanced stages, so that feel is realized as [fiw] and mall will sound somewhat like the L1 
'mal'(evil) (SILVEIRA, 2012; ZIMMER, 2004). Likewise, as Brazilian Portuguese does not allow voiced obstruents to appear in absolute word-final position, i.e., when followed by a phonetic pause, Brazilian EFL learners have been reported to realize the English word final $[-b,-d,-g,-z,-d z]$ as what auditorily are perceived as their voiceless counterparts [-p, $-t,-k,-s,-t f]$ (ZIMMER, 2004). Furthermore, according to the Markedness Differential Hypothesis (ECKMAN,1977), marknedness plays a role in the perception of final voicing since voiced codas are more marked than voiceless ones and are thus more difficult to perceive.

Previous studies have shown that voiceless stops $/ \mathrm{p} \mathrm{t} \mathrm{k} /$ in initial position pose an acquisition problem for Brazilian Portuguese learners of English (ALVES \& MAGRO, 2011; ZIMMER, 2004). This occurs because whereas the English initial voiceless stops have a long-lag VOT, Brazilian Portuguese employs unaspirated short-lag stops (VOT $>30 \mathrm{~ms}$ ), comparable to English voiceless stops followed by $/ \mathrm{s} /$. Whereas pronouncing initial voiceless stops without aspiration does not constitute a phonological error, as the speaker is substituting the contextually appropriate allophone for a contextually inappropriate one, it does contribute to the perceived foreign accent of the language learners and may affect their intelligibility.

Finally, it should be stated that many of the before-mentioned interlanguage processes have been suggested to occur not only due to differences between the L1 and the L2 segmental inventories and syllable structures, but also due to the differing sound-spelling correspondences between the languages in question. Whereas Brazilian Portuguese has a rather transparent orthography, the English orthography is more opaque, leading to systematic pronunciation errors that can be traced back to spelling (SILVEIRA, 2012; ZIMMER, 2004).

\section{RESEARCH QUESTIONS AND HYPOTHESES}

The aim of the present study was to examine whether L1 Brazilian Portuguese learners of English possess awareness about the segmental phonology of English and whether the degree of awareness would differ as a function of the type of pronunciation deviation (vowel/consonant/final voicing/VOT). The following research questions (RQs) and hypotheses $(\mathrm{Hs})$ were formed:

RQ 1. Do advanced L1 Brazilian Portuguese EFL learners possess awareness about the segmental phonology of English? 
H 1. It was hypothesized that advanced language learners would possess some degree of awareness about the L2 segments as testified by their interlanguage phonology: should no awareness exist, the perception and production of the L2 should occur wholly through the L1, or following Schmidt (1990, 1995): no noticing, no learning. However, due to the primacy of meaning over form (VANPATTEN, 1996) and the incomplete state of their L2 phonological system, it was expected that the language learners would show a lower degree of awareness than the native speakers, whose L1 phonology is stable and complete.

RQ 2. Is the awareness about L2 segments affected by the pronunciation deviation type (vowel/consonant/final voicing/VOT)?

H 2. As all the deviation types have been shown to be difficult for L1 Brazilian Portuguese EFL learners, no large differences were expected among them. However, it was hypothesized that perceptual salience might play a role. Namely, the identification of deviations involving phoneme substitution could be easier than the identification of deviations of allophonic nature such as the length of VOT.

\section{METHOD}

The current study employed a psycholinguistic perception task to investigate Brazilian Portuguese EFL learners' awareness about the segmental domain of American English. In this task, participants listened to native and nonnative pronunciations of segments of English words and decided whether the pronunciation was correct or not. Their accuracy in identifying pronunciation deviations was assumed to reflect their awareness about English phones.

\section{1. Participants}

The participants of the study were 71 native speakers of Brazilian Portuguese (mean age $=26.01$, SD $=7.63$ ) who were studying English at the Federal University of Santa Catarina (UFSC) and 18 native speakers of American English (mean age $=23.83, S D=6.76$ ) who served the purpose of providing baseline data. The L1 Brazilian Portuguese EFL learners had an upper-intermediate to advanced proficiency of English as testified by their vocabulary size $(M=4150.00$ SD $=$ 571.83, $\max =5,000$ - CEFR level C1: MILTON, 2010), which was measured with X_lex vocabulary size test (MEARA, 2005). Participants with an advanced level in 
the L2 were selected because more attentional resources are freed for processing pronunciation in the higher proficiency levels than in the lower proficiency levels (VANPATTEN, 1996).

The L1 Brazilian Portuguese EFL learners had a limited exposure to English outside the classroom context. On average, the L1 Brazilian Portuguese participants had been employing English 21.73 percent of the time $(S D=14.49)$ in the five years prior to the data collection. Only 13 percent had constant contact with native speakers of English. The mean length of stay in English speaking countries was 4.33 months $(S D=11.42)$. Moreover, 88 percent of the EFL learners had never attended a course in English phonetics and phonology, and none of the participants had received phonetic training in the semester prior to the data collection.

The American English speakers were recruited among the exchange students attending university classes in Florianópolis. ${ }^{2}$ The L1 American English participants' experience with Brazilian Portuguese was predominantly limited: 89 percent had stayed less than six months in Brazil and only 11 percent considered themselves fluent in Portuguese. On average, the L1 American English participants had studied Portuguese (either formally or informally) for 1.16 years $(S D=2.38)$.

\subsection{Instrument and procedure}

A novel task based on grammaticality judgment tasks (GJTs) was created to investigate participants' awareness about English phones. Whereas GJTs have been successfully employed in language awareness research (e.g., AMMAR, LIGHTBOWN, \& SPADA, 2010; REBUSCHAT \& WILLIAMS, 2012; RENOU, 2001), the employment of correctedness judgments has not been previously employed in the field of phonology. In the Phonological Judgment Task, participants listened to English phones and decided whether the heard segment was correct (native-like) or incorrect (non-native-like). The task consisted of 80 test trials: 51 trials spoken by L1 Brazilian Portuguese elementary English learners $(n=8)$ and 29 spoken by native English speakers $(n=2)$. The segments focused on areas which have been shown to be difficult for L1 Brazilian Portuguese EFL learners by previous research. Namely: segments /i-I, U- $\mho, æ, \Lambda, \theta, \delta, \mathrm{y} /$ delateralization (bill as [hiw]) and features of consonants final voicing (bag as [bæk]) and VOT (pool, [p $\left.\mathrm{p}^{\mathrm{h}} \mathrm{ul}\right]$ as [pul] (Table 1). The Brazilian Portuguese and American English

2 Three of the L1 AmE participants were permanently residing in Florianópolis (mean LOR $=4.08$ $y, S D=5.19$ ). Nevertheless, their task performance did not differ from the L1 AmE participants residing in the US. 
speakers were recorded individually in a quiet room or in a soundproof booth, and the productions of the L1 BP speakers were visually and auditorily inspected for the presence of the pronunciation deviations. Agreement on the presence and the nature of the pronunciation deviations with the researcher and two experienced phoneticians was $97.14 \%$. The stimuli were preprocessed for presentation by normalizing the speech samples to the same peak amplitude level and by removing any low-frequency noise.

The task was created and administered with $\mathrm{DmDx}$ display presentation software (FORSTER \& FORSTER, 2012). The test trials proceeded as follows: the test word with the target phone underlined appeared on the screen (e.g. "hill"). Next, the target phone together with the neighboring segment (CV/VC) was played twice. Finally, the participants responded by pressing the corresponding keyboard key whether the underlined segment was native-like or not (E.g. "Was the sound at the end of the word 'hill' target-like?"). Participants received instructions that they were to make their decision based on the underlined part only, although they would hear a bit more of the word for the sake of making the task easier. The trials could be relistened as many times necessary, but the response could not be changed. Response ('yes'/'no') was given by pressing the corresponding Control key on the keyboard. The order of the trials was randomized. The CV/VC presentation of the target phones was selected due to the low auditory salience of consonants: as consonants are not auditorily salient in isolation, judging their correctness is difficult without the presence of a vowel. In order to have a uniform task structure, the same CV/VC presentation was also employed for the vowel trials.

Mean identification accuracy was obtained for individual trials as well as to trials spoken by native and non-native speakers. The ability to identify pronunciation deviations in non-native speech (accuracy in non-native speaker trials) was taken as an indication of phonological awareness about the L2 segmental phonology. This is because being able to identify a pronunciation deviation requires complex mental processing, whereas the ability to accept native pronunciations as correct 


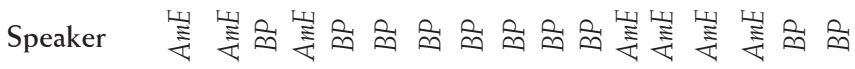

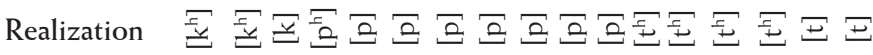

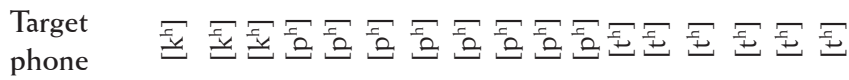

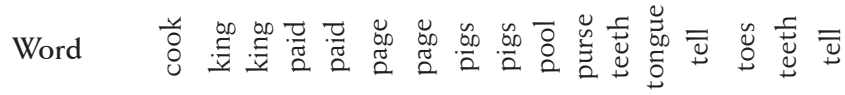

Target area

VOT

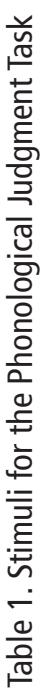

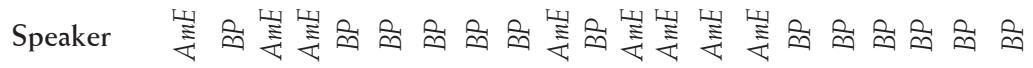

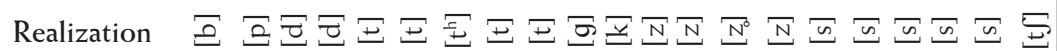

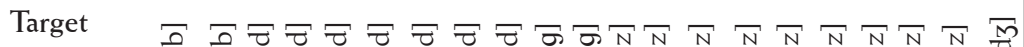

phone

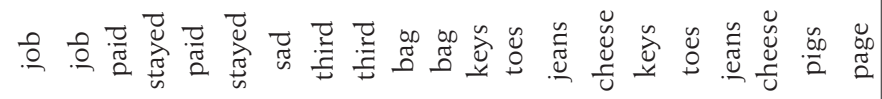

Target area

Final voicing

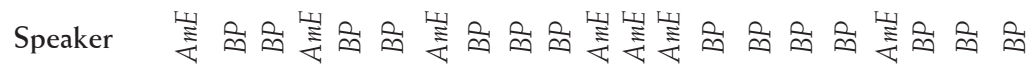

Realization

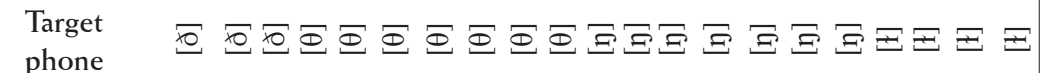

phord

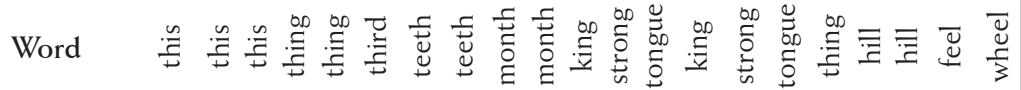

Target area

Consonant

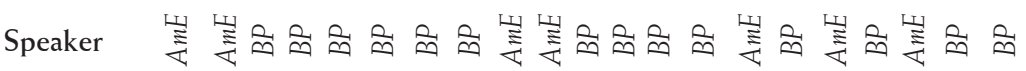

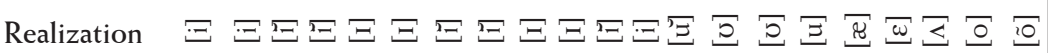

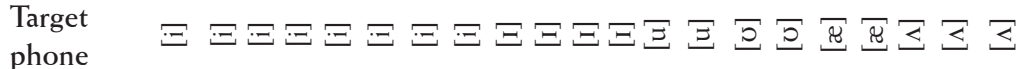

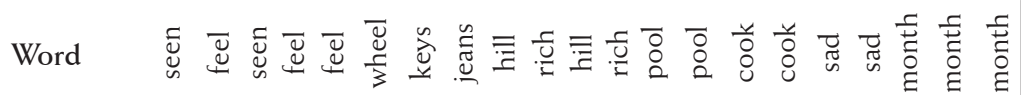

Target area

Vowel 
In identifying a pronunciation deviation, the listener first needs to perceive the stimulus accurately so that it can be processed. Next, the heard stimulus needs to be compared to the listener's mental representation of the L2 target. Finally, if no match is found, the heard stimulus needs to be rejected. An alpha level of .05 was use for all statistical tests.

\section{RESULTS}

\subsection{Awareness about L2 segments}

Pronunciation deviations present in the non-native speaker trials were identified poorly as manifested by the mean accuracy scores of both participant groups (Table 2). Nevertheless, performance in the native speaker trials was nearly equally high for L1 Brazilian Portuguese and L1 American English participants. As expected, the identification accuracy scores of the EFL learners were lower than the native English speaker scores in both trial types.

Table 2. Mean identification accuracy (\%) for the native and non-native speaker trials.

\begin{tabular}{|c|c|c|c|c|}
\hline \multirow[b]{3}{*}{ Trial } & \multicolumn{4}{|c|}{ Listener L1 } \\
\hline & \multicolumn{2}{|c|}{$\mathrm{BP}(\mathrm{n}=71)$} & \multicolumn{2}{|c|}{$\operatorname{AmE}(n=18)$} \\
\hline & $M$ & $S D$ & $M$ & $S D$ \\
\hline Non-native $(\mathrm{n}=51)$ & 42.61 & 16.16 & 68.84 & 13.31 \\
\hline Native $(n=29)$ & 85.18 & 8.94 & 87.35 & 8.10 \\
\hline
\end{tabular}

In order to determine whether the L1 Brazilian Portuguese EFL learners possessed awareness about the L2 phones (RQ 1), the mean identification accuracy percentages in the native speaker (correct) and non-native speaker (incorrect) trials were examined and compared to the native control group performance. A mixed ANOVA was conducted with Trial (native/ non-native) as the within-subjects variable, Listener $L_{1}(\mathrm{BP} / \mathrm{AmE})$ as the between-subjects variable and Identification Accuracy as the dependent measure.

The ANOVA showed a significant main effect of Trial, $F(1,87)=149.49$, $p<.001, \eta^{2}=.63$, Listener $L_{1} F(1,87)=40.56, p<.001, \eta^{2}=.31$, as well as a Trial $\mathrm{x}$ Listener $L_{1}$ interaction $F(1,87)=23.19, p<.001, \eta^{2}=.21$. The interaction effect, as confirmed by post-hoc tests, occurred because the two participant groups did not differ significantly in the identification accuracy for the native speaker trials, $t(87)=-.93, p=.352$. In other words, both participant groups accepted native 
speaker pronunciations as correct to the same extent. The significant main effect of Trial indicated that, as expected, for both participant groups, the identification of non-native speaker deviations was more difficult than the acceptance of native speaker pronunciations. More importantly, the significant main effect of Listener L1 showed that the L1 Brazilian Portuguese participants manifested a significantly poorer identification accuracy in the non-native speaker trials than the L1 American English participants, as could be expected for foreign language learners (Figure 1).

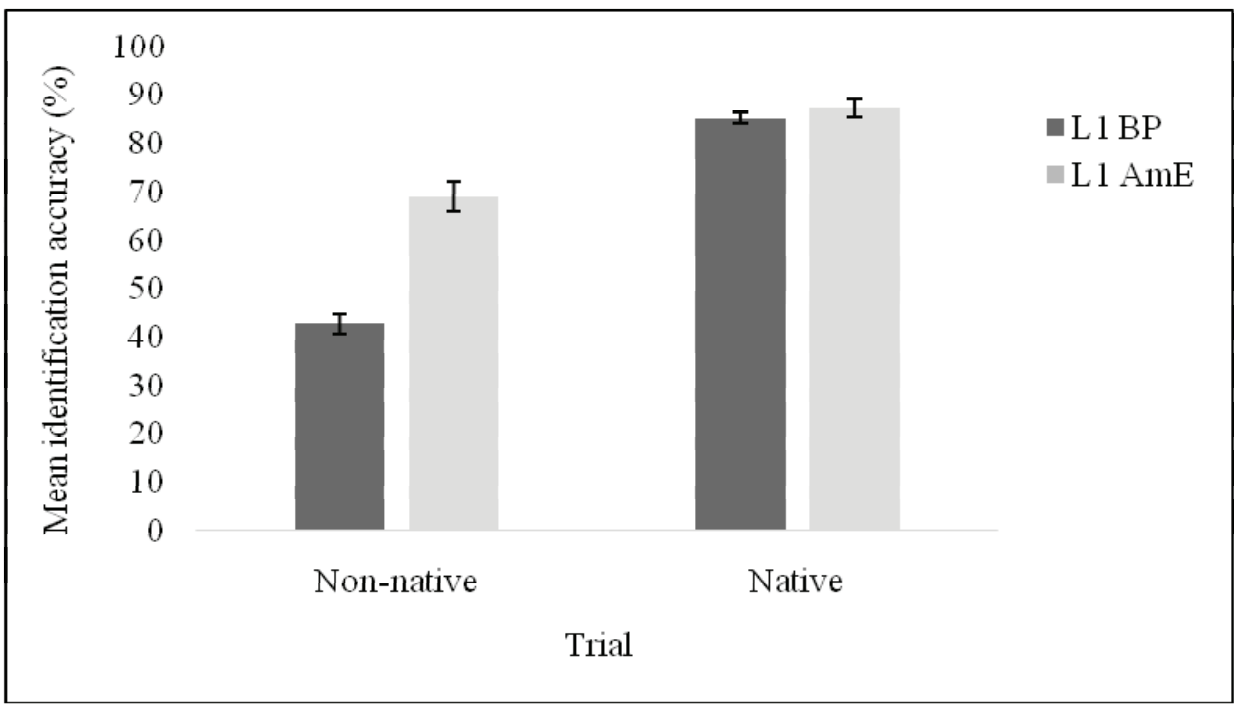

Figure 1. Mean identification accuracy for native and non-native speaker trials (error bars represent \pm 1 standard error).

\subsection{Awareness across pronunciation deviation types}

Having established that identifying non-native speaker pronunciation deviations was rather challenging for both participant groups (L1 BP $M=42.61$, L1 AmE $M=68.84$ ), awareness about each deviation type (vowel/consonant/final voicing/VOT) was examined next. Namely, the objective was to determine whether the L1 Brazilian Portuguese learners of English would show more awareness about one deviation type over another (RQ 2). With this aim, deviation identification accuracy in the non-native speaker trials was calculated.

The L1 Brazilian Portuguese participants' identification accuracy was below chance level in all deviation types except Consonant (Table 3). The L1 American English participants showed consistently higher accuracy rates than the L1 Brazilian 
Portuguese EFL learners. For both participant groups, the lowest identification accuracy occurred in the VOT category. In order to examine whether the observed differences in the identification accuracy would be statistically significant, a mixed ANOVA with Bonferroni corrected pairwise comparisons was conducted. The within-subjects factor was Pronunciation Deviation Type (Consonant/Vowel/ Final Voicing/ VOT), the between-groups factor was Listener L1 (BP/AmE) and the dependent factor was Deviation Identification Accuracy.

Table 3. Mean identification accuracy (\%) across deviation types for L1 BP and L1 AmE participants.

\begin{tabular}{|c|c|c|c|c|}
\hline \multirow[b]{2}{*}{ Deviation type } & \multicolumn{2}{|c|}{ L1 BP $(n=71)$} & \multicolumn{2}{|c|}{ L1 $\operatorname{AmE}(n=18)$} \\
\hline & $M$ & $S D$ & $M$ & $S D$ \\
\hline Consonant & 51.50 & 21.11 & 71.42 & 13.85 \\
\hline Vowel & 41.64 & 20.13 & 74.20 & 12.03 \\
\hline Final voicing & 41.49 & 16.72 & 72.22 & 16.92 \\
\hline VOT & 32.95 & 26.47 & 53.33 & 26.78 \\
\hline
\end{tabular}

The ANOVA showed a significant main effect of Pronunciation Deviation Type, $F(3,85)=11.24, p<.001, \eta^{2}=.28$, as well as a significant main effect of $L_{1}, F(1$, $87)=37.85, p<.001, \eta^{2}=.30$. The interaction between Pronunciation Deviation Type $\mathrm{x} L 1$ was also significant, $F(3,85)=2.87, p=.041, \eta^{2}=.09$. The interaction effect occurred because the mistake identification accuracy in some of the pronunciation deviation types did not differ significantly. This was the case with Consonant-Vowel $(p=1.00)$, Consonant- Final Voicing $(p=.394)$ and Vowel-Final Voicing $(p=1.00)$. VOT differed significantly from all deviation types $(p<.001)$.

The results showed that the L1 Brazilian Portuguese EFLlearners manifested a significantly poorer deviation identification accuracy in all categories in comparison to the native English speakers $(\phi<.001)$. Additionally, the results revealed that whereas the deviation identification accuracy in Consonant, Vowel and Final Voicing was similar $(p>.05)$, the identification of short-lag VOT items was significantly more difficult than the identification of the other deviation types (Figure 2). One possible reason as to why items with short-lag VOT were identified as erroneous with more difficulty is that contrary to the other deviation types, VOT involves allophonic, not phonological variation. Thus, it is likely that the perceptual salience of allophonic variation is lower than that of phonological variation making it more difficult to perceive deviations of allophonic nature. This seems to be supported by the fact that the VOT category was also the most difficult for the native control group. 


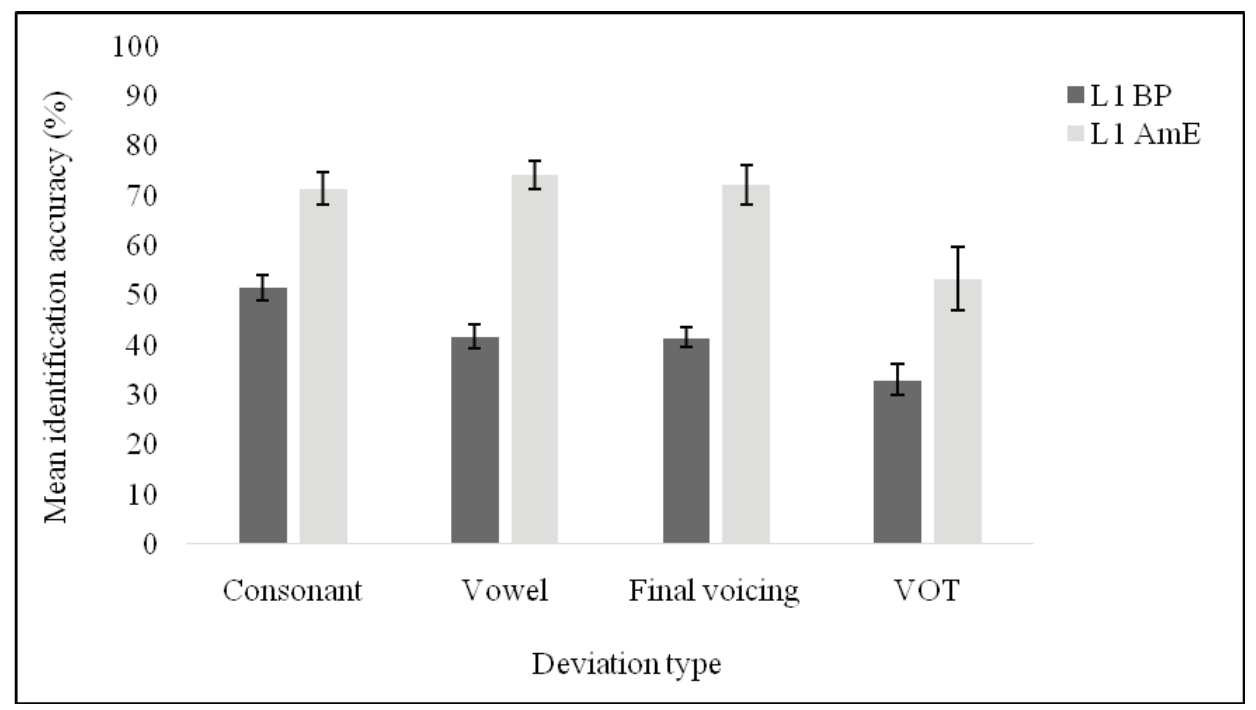

Figure 2. Mean identification accuracy for non-native speaker trials across deviation types (error bars represent \pm 1 standard error).

\section{DISCUSSION AND CONCLUSIONS}

The present study investigated the under-researched area of non-verbalizable phonological awareness by examining L1 Brazilian Portuguese EFL learners' awareness about English phones with perceptual phonological judgments. The results revealed, on the one hand, that L1 Brazilian Portuguese learners of English manifested poor awareness about English phones, underperforming native English speakers and performing at or below chance level in all test categories. Whereas accuracy was equally high to native English speakers in the native-speaker trials, the identification of pronunciation deviations in non-native speaker trials was poor. This suggests that although the L1 Brazilian Portuguese participants' awareness about deviant L2 segments was poor, they did show some degree of awareness, as they were able to accept native pronunciations as correct to the same extent with the native English speakers. On the other hand, it was seen that pronunciation deviations involving non-target-like VOTs were identified with the highest difficulty, whereas pronunciation deviations presenting non-target-like consonants were noticed with the most ease.

Perhaps a surprising finding of the study was that even advanced language learners (CEFR level C1) were highly unaware of the segmental inventory of the 
L2. As L2 phonological awareness is expected to develop through contact with the target language, it would be expected that advanced language learners, like those tested in this study, would show higher awareness about the L2 phonology. This is especially true if the neurological processing of the L2 in advanced levels of learning is taken into account. When language learners reach the state in which the output is automatized and fluent, attentional resources can be directed from the searching of the right meaning to focusing on the accuracy of the speech (VANPATTEN, 1996).

Task structure could be one of the reasons to why the L1 Brazilian Portuguese learners of English manifested such a low degree of awareness. The segments were presented in isolation and thus their presentation was fast and some of the segments might not have had high enough auditory salience to be perceived. In order to ease the processing demands in a task requiring such a high degree of attentional resources, the stimuli were played twice and the participants had the option to relisten as many times as they wished, an option which was not largely employed (relistening rate $M=4.43 \%$ ). Additionally, all the segments were selected due to their difficulty for L1 Brazilian EFL learners. Native speakers did not perform to ceiling level either, suggesting that they also found the task difficult. Moreover, being that most of the participants were phonetically-naïve, listening to phones in isolation and thinking about their accuracy must have required skills that the participants were not used to employing.

However, these results are not unheard of in previous research on nonverbalizable and verbalizable L2 phonological awareness. Kennedy (2012) found no relation between the amount of L2 use and verbalizable L2 phonological awareness in ESL language learners living in Montreal. Likewise, Venkatagiri and Levis (2007) failed to find a relation between the number of years of L2 study or the number of months living in the L2 country and explicit L2 phonological awareness.

Two possible reasons as to why even advanced language learners show only a low-level awareness to L2 phonology are discussed next. On the one hand, it is possible that the exposure the L2 learners have to the foreign language is too limited for real benefits to appear. This is especially true in foreign language setting, although it should be noted that the participants in Kennedy (2012) and Venkatagiri and Levis (2007) were living in immersion setting. In the case of the participants in the present study, the limited exposure to English is a possible factor to their low degree of L2 phonological awareness. As detailed in the methodology section, most of the participants' contact with English occurred in the English language classes 
at the university (a few times a week) and only 13 percent of the participants had constant contact with native speakers of English.

Another possibility is that even though language learners would be extensively exposed to L2 input, regular L2 input might not make the phonological aspects of the L2 salient enough for noticing to occur (KIVISTÖ-DE SOUZA, 2015). To put another way, it could be that phonology cannot simply be 'picked up' from contact with the L2 but that specific phonetic instruction is necessary to draw language learners' attention to L2 phonology. This issue will be furtherdeveloped.

Another finding of the study was that although the L1 Brazilian Portuguese participants' awareness was low overall, differences were observed as a function of the type of pronunciation deviation. Whereas the identification accuracy between deviations involving consonants, vowels and final voicing did not differ significantly, the identification accuracy of pronunciation deviations presenting short-lag VOTs was the poorest. The VOT category differs from the others in that it presents noncontrastive units used to signal contextual allophonic variation. Previous studies on L2 phonological awareness have shown that L2 learners possess some degree of awareness about VOT. Author (2014) used a delayed mimicry paradigm in which L1 Spanish participants were asked to produce words with voiceless plosives in three conditions: L2 English, L1 Spanish and English-accented Spanish. The results showed that the participants were able to modify their VOT timing when imitating English-accented Spanish, which was interpreted as learners having developed awareness about the VOT difference between L1 and L2 plosives (short- vs. longlag). Same task design was previously employed in Flege and Hammond (1982) and Zuengler (1988), with the difference that these latter did not employ foreign language learners but native speakers who were familiar with L2-accented speech. The results from these studies also suggest that language users are aware of VOT differences across languages, and use this feature to characterize foreign speakers when asked to imitate their speech.

Nevertheless, in examining French learners of English, Shoemaker (2014) discovered that $1^{\text {st }}$ and $3^{\text {rd }}$ year majors had difficulties in employing aspiration as a cue signaling word boundaries ( $\sim 60 \%$ accuracy). The author concludes that aspiration, independently of the learner's L1 background, might not be perceptually very salient to be noticed by L2 learners. This explanation seems plausible when taken into consideration the native speaker behavior in the present study. Whereas the L1 American English speakers identified the VOT items significantly better than the L1 Brazilian Portuguese EFL learners (53\% cf. 32\%), the native English speakers also showed the lowest identification accuracy in the VOT stimuli. Moreover, as 
short-lag and long-lag /p t k/ are allophonic variants in English and thus employing them interchangeably will not change meaning, it is possible that their form is less attended to, by native and non-native speakers alike, than the form of vowels and consonants signaling a contrastive difference, such as fell-fill or mat-hat, for example (VANPATTEN, 1996).

An additional explanation to the L1 Brazilian Portuguese EFL learners' poor identification of stimuli presenting inadequate VOTs is proposed by Alves and Zimmer (2015). The authors suggest, based on perception and production data with 34 Brazilian EFL learners, that Brazilians Portuguese speakers might not use VOT as the primary cue to differentiate between English voiceless and voiced plosives, contrary to native English speakers. Instead, they would employ other cues such as the burst intensity of the plosive (voiced sounds are pronounced with less muscular force than voiceless sounds) and/or the F0 of the following vowel. It would thus seem that building awareness and acquiring native-English-like VOT patterns might be especially challenging for L1 Brazilian Portuguese speakers.

Explicit phonetics instruction might be helpful in bringing VOT differences into L1 Brazilian Portuguese EFL learners' awareness. As mentioned earlier, the results of the present study suggest that it is possible that regular L2 input is not enough for L2 phonological awareness to develop extensively. It could be that most of the foreign language learners would benefit from explicit phonetics instruction in order to gain awareness about L1-L2 phonological differences. In the light of the results of the present study, it seems that the segmental phonology of the L2 can present difficulties for L1 Brazilian Portuguese learners of English. This will have an effect on L2 perception as well as production, as the dominating view in L2 acquisition is that in order to learn a linguistic aspect, it first has to be consciously noticed (eg., ELLIS, 2005; ROBINSON, 2003; SCHMIDT, 1990). In order to improve L2 learners' speech accuracy and to develop more effective pronunciation instruction strategies, it is necessary to determine what aspects of L2 phonology the learners are and are not aware of. Once the problem areas are determined, the instructor can aid the learner to notice the relevant aspects by employing consciousness-raising activities.

The use of consciousness-raising activities has a long history in language awareness research and several teaching methods, such as Focus on Form (LONG, 1991), Processing Instruction (VANPATTEN, 2002) and Input Enhancement (SHARWOOD SMITH, 1991), have been created around the idea of increasing language learners' consciousness of the target language. The employment of activities that bring specific aspects of language into the learners' consciousness 
has been shown to be beneficial for their accurate acquisition (eg., ALANEN, 1995; BERGSLEITHNER \& BORGES MOTA, 2013; ROBINSON, 1995; ROSA \& LEOW, 2004).

In the field of L2 phonological acquisition, a large body of research exists about the benefits of perceptual training and explicit phonetics instruction on the accurate acquisition of target phonological structures (e.g. ALVES \& MAGRO, 2011; CEBRIAN \& CARLET 2014; COUPER, 2011; RAMÍREZ VERDUGO, 2006; RATO, 2013; SAITO, 2015; SILVEIRA, 2004; WREMBEL, 2005). As brought up by Silveira and Alves (2009), the instructor can have the facilitating role in helping learners to notice details of L2 speech which otherwise may be left unnoticed. It is only through noticing, that the stimulus can be further processed, stored in the long-term memory and retrieved when needed (ELLIS, 2005). Therefore, by determining the gaps in L2 learners' phonological awareness, such as awareness about final voicing or VOT, for example, and by addressing these gaps through explicit instruction, foreign language instructors can play a vital role in aiding learners to improve their L2 pronunciation accuracy.

Although little is yet known about L2 phonological awareness, its relation to the development of L2 pronunciation accuracy makes it a promising field to investigate. Future studies should continue to determine gaps in language learners' awareness about L2 phonology and to investigate what type of instruction is the most effective in bringing them into the learners' consciousness. Furthermore, language learners should be given tools on how to raise phonological awareness on their own in the absence of instruction, as becoming interested and motivated about improving pronunciation outside the classroom is likely to lead into superior and more lasting outcomes.

\section{REFERENCES}

ALANEN, R. (1995). Input enhancement and rule presentation in second language acquisition. In R. Schmidt (Ed.), Attention and awareness in foreign language learning and teaching. Second Language Teaching and Curriculum Center Technical Report No. 9 (pp. 259-302). Honolulu: University of Hawai'i Press.

ALVES, U. K. (2009). Consciência dos aspectos fonético-fonológicos da L2. In R. Lamprecht (Ed.), Consciência dos sons da língua: Subsídios teóricos e práticos para alfabetizadores, fonoaudiólogos e professores de língua inglesa (pp. 201-231). Porto Alegre: EDIPUCRS. 
ALVES, U. K., \& MAGRO, V. (2011). Raising awareness of L2 phonology: Explicit instruction and the acquisition of aspirated /p/ by Brazilian Portuguese speakers. Letras de Hoje, 46, pp. 71-80.

ALVES, U. K., \& ZIMMER, M.C. (2015). Percepção e produção dos padrões de vot do inglês por aprendizes brasileiros: $\mathrm{O}$ papel de múltiplas pistas acústicas sob uma perspectiva dinâmica. Alfa, 59, pp. 157-180.

AMMAR, A., LIGHTBOWN, P., \& SPADA, N. (2010). Awareness of L1/L2 differences: Does it matter? Language Awareness, 19, pp. 129-146.

BAKER, W., \& TROFIMOVICH, P. (2006). Perceptual paths to accurate production of L2 vowels: The role of individual differences. International review of Applied Linguistics in Language Teaching, 44, pp. 231-250.

BAPTISTA, B. O. (2006). Adult phonetic learning of a second language vowel system. In B. O. Baptista \& M. A. Watkins (Eds.), English with a Latin beat: Studies in Portuguese/ SpanishEnglish interphonology (pp. 25-46). Amsterdam: John Benjamins.

BAPTISTA, B. O., \& SILVA FILHO, J. (2006). The influence of voicing and sonority relationships on the production of English final consonants. In B. O. Baptista \& M. A. Watkins (Eds.), English with a Latin beat: Studies in Portuguese/ Spanish-English interphonology (pp. 73-90). Amsterdam: John Benjamins.

BERGSLEITHNER, J., \& BORGES MOTA, M. (2013). Investigating relationships among noticing, working memory capacity, and accuracy in L2 oral performance. In J. Bergsleithner, S. Frota \& J. Yoshioka (Eds.), Noticing and second language acduisition: Studies in bonor of Richard Scbmidt (pp. 151-168). Honolulu: University of Hawai'i, National Foreign Language Resource Center.

BRADLEY, L., \& BRYANT, P. E. (1983). Categorizing sound and learning to read: A causal connection. Nature, 301, pp. 419-421.

CABANERO, M., \& ALVES, U. K. (2008). A transferência grafo-fônico-fonológica na produção de seqüencias ortográficas 'ng' do inglês (L2): Uma abordagem conexionista. Revista Virtual de Estudos da Linguagem, 6. Retrieved from http://www.revel. inf.br

CARDOSO, W. (2005). The variable acquisition of English word-final stops by Brazilian Portuguese speakers. In L. Dekydtspotter, R. A. Sprouse, \& A. Liljestrand (Eds.), Proceedings of the 7th Generative Approaches to Second Language Acquisition Conference (pp. 3849). Somerville, MA: Cascadilla Proceedings Project.

CEBRIAN, J. \& CARLET, A. (2014). Second language learners' identification of target language phonemes: A short-term phonetic training study. Canadian Modern Language Review, 70, pp. 474-499.

COUPER, G. (2011). What makes pronunciation teaching work? Testing for the effect of two variables: socially constructed metalanguage and critical listening. Language Awareness, 20, pp. 159-182. 
DEFIOR, S., GUTIÉRREZ-PALMA, N., \& CANO-MARÍN, M.J. (2012). Prosodic awareness skills and literacy acquisition in Spanish. Journal of Psycholinguistic Research. 41, pp. 285-294.

ECKMAN, F. R. (1977). Markedness and the contrastive analysis hypothesis. Language learning, 27(2), pp. 315-330.

ELLIS, N. C. (2002). Reflections on frequency effects in language processing. Studies in Second Language Acquisition, 24, pp. 297-339.

ELLIS, N. C. (2005). At the interface: Dynamic interactions of explicit and implicit language knowledge. Studies in Second Language Acquisition, 27, pp. 305-352.

FLEGE, J. (1995). Second language speech learning, theory, findings and problems. In W. Strange (Ed.), Speech perception and linguistic experience: Issues in cross-language research (pp. 233-277). Timonium, MD: York Press.

FLEGE, J., \& HAMMOND, R. (1982). Mimicry of non-distinctive phonetic differences between language varieties. Studies in Second Language Acquisition, 5, pp. 1-17.

FORSTER, K. I., \& FORSTER, J.C. (2012). DMDX (Version 4.0.6.0) [Computer software]. Retrieved from http://www.u.arizona.edu/ jforster/dmdx.htm

FOY, J., \& MANN, V. (2001). Does strength of phonological representations predict phonological awareness in preschool children? Applied Psycholinguistics, 22, pp. 301-325.

GONÇALVES, A. (2014). In search of speech intelligibility: The case of English bigh front vowels (Unpublished Master's thesis). Federal University of Santa Catarina, Florianópolis. SC.

GOSWAMI, U., \& BRYANT, P. (1990). Phonological skills and learning to read. Hillsdale, NJ: Lawrence Erlbaum.

KENNEDY, S. (2012). Exploring the relationship between language awareness and second language use. TESOL Quarterly, 46, pp. 398-408.

KENNEDY, S., BLANCHET, J., \& TROFIMOVICH, P. (2014). Learner pronunciation, awareness, and instruction in French as a second language. Foreign Language Annals, 47, pp. 79-96.

KENNEDY, S., \& TROFIMOVICH, P. (2010). Language awareness and second language pronunciation: a classroom study. Language Awareness, 19, pp. 171-185.

KIVISTÖ-DE SOUZA, H. (2015). Phonological awareness and pronunciation in a second language. Unpublished doctoral dissertation. University of Barcelona, Barcelona, Spain.

LEHTONEN, A., \& TREIMAN, R. (2007). Adults' knowledge of phoneme-letter relationships is phonology based and flexible. Applied Psycholinguistics, 28, pp. 95-114.

LEOW, R. (1997). Attention, awareness and foreign language behavior. Language Learning, 47, pp. 467-505.

LONG, M. H. (1991). Focus on form: A design feature in language teaching methodology. In K. de Bot, R. Ginsberg, \& C. Kramsch (Eds.), Foreign language research in cross-cultural perspective (pp. 39-52). Amsterdam: John Benjamins. 
MCBRIDE-CHANG, C. (1995). What is phonological awareness? Journal of Educational Psychology, 87, pp. 179-192.

MEARA, P. M. (2005). X_Lex: The Swansea vocabulary levels test (Version 2.05.) [Computer software]. Swansea: Lognostics.

MILTON, J. (2010). The development of vocabulary breadth across the CEFR levels: A common basis for the elaboration of language syllabuses, curriculum guidelines, examinations, and textbooks across Europe. In I. Bartning, M. Martin, \& I. Vedder (Eds.), Eurosla Monograpbs Series 1: Communicative Proficiency and Linguistic Development (pp. 211-232). Retrieved from http://eurosla.org/monographs/EM01/EM01tot. pdf

MORA, J.C., ROCHDI, Y., \& KIVISTÖ-DE SOUZA, H. (2014). Mimicking accented speech as L2 phonological awareness. Language Awareness, v.23, n. 1-2, pp. 57-75.

OAKHILL, J., \& KYLE, F. (2000). The relation between phonological awareness and working memory. Journal of Experimental Cbild Psychology, 75, pp. 152-164.

PISKE, T. (2008). Phonetic awareness, phonetic sensitivity and the second language learner. In J. Cenoz \& N. H. Hornberger (Eds.), Encyclopedia of language and education Vol. 6: Knowledge about language (pp. 155-166). New York: Springer Science.

RAMÍREZ VERDUGO, D. (2006). A study of intonation awareness and learning in nonnative speakers of English. Language Awareness, 15, pp. 141-159.

RATO, A. (2013). Cross-language perception and production of English vowels by Portuguese learners: The effects of perceptual training (Unpublished Doctoral dissertation). University of Minho, Minho.

RAUBER, A. (2006). Perception and production of English vowels by Brazilian EFL speakers (Unpublished Doctoral dissertation). Federal University of Santa Catarina, Florianópolis, SC.

REBUSCHAT, P., \& WILLIAMS, J. (2012). Implicit and explicit knowledge in second language acquisition. Applied Psycholinguistics. 33, pp. 829-856.

REIS, M. S. (2006). The perception and production of English interdental fricatives by Brazilian EFL learners (Unpublished Master's thesis). Federal University of Santa Catarina, Florianópolis, SC.

RENOU, J. (2001). An examination of the relationship between metalinguistic awareness and second-language proficiency of adult learners of French. Language Awareness, 10, pp. 248-267.

ROBINSON, P. (1995). Attention, memory and the 'noticing' hypothesis. Language Learning, 45, pp. 283-331.

ROBINSON, P. (2003). Attention and memory during SLA. In C. Doughty \& M. Long (Eds.), The bandbook of second language acquisition (pp. 631-678). New York: Blackwell.

ROSA, E., \& LEOW, R. (2004). Awareness, different learning conditions, and second language development. Applied Psycholinguistics, 25, pp. 269-292.

ROSA, E., \& O’NEILL, M. (1999). Explicitness, intake, and the issue of awareness. Studies in Second Language Acquisition, 21, pp. 511-556. 
SAITO, K. (2015). Communicative focus on second language phonetic form: Teaching Japanese learners to perceive and produce English /x/ without explicit instruction. Applied Psycholinguistics, 36, pp. 377-409.

SCARBOROUGH, H., EHRI, L., OLSON, R., \& FOWLER, A. (1998). The fate of phonemic awareness beyond the elementary school years. Scientific Studies of Reading 2, pp. 115-142.

SCHMIDT, R. (1990). The role of consciousness in second language learning. Applied Linguistics, 11, pp. 129-158.

SCHMIDT, R. (1995). Consciousness and foreign language learning: a tutorial on the role of attention and awareness in learning. In Schmidt, R. (Ed.), Attention and awareness (pp. 1-63). Honolulu, HI: University of Hawai`i, National Foreign Language Resource Center.

SHARWOOD SMITH, M. A. (1991). Speaking to many minds: On the relevance of different types of language information for the L2 learner. Second Language Research, 7, pp. 118-132.

SHOEMAKER, E. (2014). The exploitation of subphonemic acoustic detail in L2 speech segmentation. Studies in Second Language Acquisition, 36, pp. 709-731.

SILVEIRA, R. (2002). Perception and production of English initial/s/ clusters by Brazilian learners. Revista Brasileira de Linguística Aplicada, 2, pp. 95-119.

SILVEIRA, R. (2004). The influence of pronunciation instruction on the perception and production of English word-final consonants (Unpublished Doctoral dissertation). Federal University of Santa Catarina, Florianópolis, SC.

SILVEIRA, R. (2012). PL2 production of English word-final consonants: The role of orthography and learner profile variables. Trabalbos em Linguística Aplicada, 51, pp. 13-34.

SILVEIRA, R., \& ALVES, U.K. (2009). Noticing e instrução explícita: Aprendizagem fonético-fonológica do morfema-ed. Nonada, 13, pp. 149-159.

STANOVICH, K. E. (1992). Speculations on the causes and consequences of individual differences in the acquisition of reading skills. Psychological Bulletin, 101, pp. 192-212

TARONE, E., \& BIGELOW, M. (2005). Impact of literacy on oral language processing: Implications for second language acquisition research. Annual Review of Applied Linguistics, 25, pp. 77-97.

VANPATTEN, B. (1996). Input processing and grammar instruction in second language acquisition. Norwood: Ablex Publishing

VANPATTEN, B. (2002). Processing instruction: An update. Language Learning, 52, 755-803.

VENKATAGIRI, H. S., \& LEVIS, J. (2007). Phonological awareness and speech comprehensibility: An exploratory study. Language Awareness, 16, pp. 263-277.

WREMBEL, M. (2005). Phonological Metacompetence in the Acquisition of Second Language Phonetics (Unpublished Doctoral dissertation). Adam Mickiewicz University, Poznan. 
WREMBEL, M. (2011). Metaphonetic awareness in the production of speech. In M. Pawlak, E. Waniek-Klimczak \& J. Majer (Eds.), Speaking and instructed foreign language acquisition (pp. 169-182). Clevedon: Multilingual Matters.

WREMBEL, M. (2013). Metalinguistic awareness in third language phonological acquisition. In K. Roehr \& G. A. Gánem-Gutiérrez (Eds.), The metalinguistic dimension in instructed second language learning (pp. 119-144). London: Bloomsbury.

WREMBEL, M. (2015). Metaphonological awareness in multilinguals: A case of L3 Polish. Language Awareness, 24, pp. 60-83.

YOPP, H. K. (1988). The validity and reliability of phonemic awareness tests. Reading Research Quarterly, 23, pp. 159-177.

ZIMMER, M. (2004). A transferência do conbecimento fonético-fonológico do português brasileiro (L1) para o inglês (L2) na recodificação leitora: uma abordagem conexionista (Unpublished Doctoral dissertation). Pontifícia Universidade Católica do Rio Grande do Sul, Porto Alegre, RS.

ZUENGLER, J. (1988). Identity markers and L2 pronunciation. Studies in Second Language Acquisition, 10, pp. 33-49.

Recebido: 18/04/2016

Aceito: 18/01/2017 